\title{
New EC commissioner is seen as friend of basic research
}

\begin{abstract}
Brussels. The arrival of Antonio Ruberti as the new research commissioner for the European Communities (EC) has raised hopes that basic research will have a higher profile in the EC's forthcoming Framework programme. He would like by June to win approval for the five-year ECU14.7 billion (US $\$ 19$ billion) programme, which begins in 1994, and then turn towards persuading member countries to take more of a 'bottoms-up' approach to research projects.
\end{abstract}

Ruberti, 66, has an appropriate background for the job. An electronics engineer

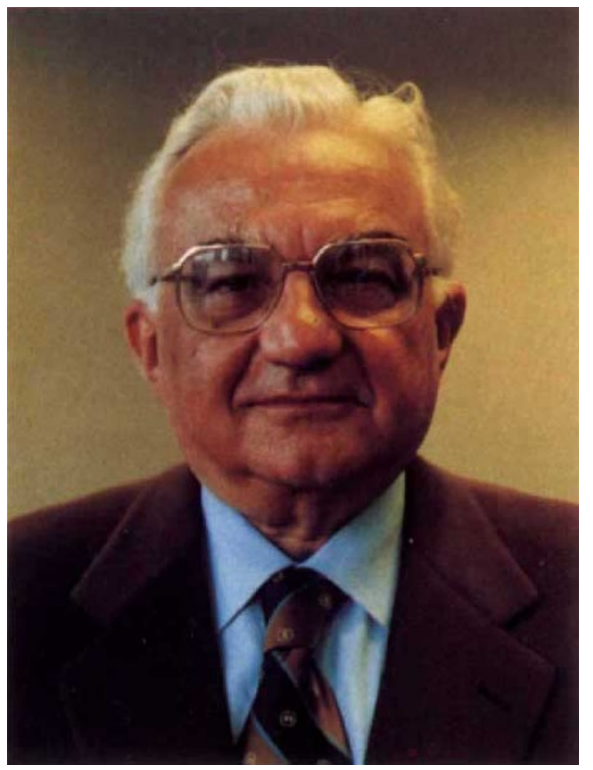

Ruberti works on Framework.

by training, he was rector of the University of Rome for more than a decade before becoming Italy's Minister for Research in 1987. Losing that post after last spring's general elections, he won a seat in the Italian Parliament for the first time as a candidate of the Socialist Party.

In a country fraught with political connivance and corruption, Ruberti emerged from government service with his integrity untainted and with the respect of the scientific community. His main achievement was to unite research and universities under a single ministry, allowing him to raise the national profile of research and to win greater autonomy for the notoriously overcentralized university system. He was responsible for the creation of the Italian Space Agency (ASI) and for many major national research programmes, including the Antarctic programme.

Ruberti's arrival, which reportedly has already brought a friendlier style to the way the commission operates, coincides with an organizational shakeup that includes merg- ing education with research. He believes that the new arrangement will lead to greater exchanges among faculty now that Europe is an open market for professors. "It is an important experiment to put education and research together", he says.

The commission is waiting to see how far Ruberti will go in reversing the legacy of his predecessor, Filippo Pandolfi, a non-scientist who was criticized for pushing EC research too far towards industry at the expense of basic research. Ruberti believes that the EC should have much closer links to, but not overlap with, the independent Eureka programme which undertakes to promote industrial research throughout the EC countries and beyond. Although he plans to go forward with the Framework programme drawn up by Pandolfi, he says that he is not afraid of change and that some amendments are to be expected.

On the other hand, some fairly fundamental changes in procedures are promised. Ruberti is keen to give national research councils a larger voice in the directing of EC funds, and he strongly supports greater cooperation at all levels between countries. With such goals in mind, it is not surprising that Ruberti embraces the Human Capital and Mobility Programme, which sponsors the movement of young researchers within Europe. Infamous for its labyrinthine complexities, this programme is a major feature of Pandolfi's fourth Framework budget, and Ruberti is not unduly alarmed by complaints about its tortuous application procedures followed by incomprehensible delays in funding.

Those delays could worsen under the Maastricht Treaty, which requires major proposals to be approved by all three EC bodies - the Commission, the Council of Ministers and the European Parliament. At present the council receives advice but decides unilaterally. Ruberti believes that requiring codecisions will reduce delays. But staff at the commission do not share his optimism, believing that gaining the initial approval process will be quite lengthy.

Ruberti's research portfolio will be more restricted than that of Pandolfi's. The organizational changes have moved some of the more industrially relevant research, notably telecommunications and informatics, which make up 40 per cent of the budget, into the industrial commission, headed by Martin Bangemann, a former German economics minister.

Ruberti hopes that a first draft of the fourth Framework programme will be ready by the end of February and be approved before Denmark relinquishes the EC presidency in June.

\section{Lawyer named minister for German research}

Munich. German Chancellor Helmut Kohl has named a strong advocate of linking science to economic development as the country's new research minister. Matthias Wissmann, a lawyer and former Christian Democrat economics spokesman, was last week chosen to succeed Heinz Riesenhuber, who has served in the post for more than a decade, as part of a modest government reshuffle.

Kohl explained his surprise move by saying that he wanted a younger cabinet (Wissmann is 43 and Riesenhuber 57) in the run-up to the 1994 elections and one with greater geographical diversity. But a more political motive may also underlie the decision: a desire to tie research policy more closely to economic policy. A chemist by training, Riesenhuber was seen as a champion of science who fiercely defended the budgets of both basic and applied research.

Wissmann believes in close links between "intelligent economic policy" and research politics. He is particularly supportive of the rebuilding of industrial research in the new eastern states and will fight for spending an additional DM150 million (US\$100 million) above the DM750 million already promised this year for specific applied research programmes in the former East Germany. As for Riesenhuber, Kohl has offered him a new - and only vaguely defined - role to "enhance scientific collaborations with the United States and Japan".

Alison Abbott

\section{Clinton lifts ban on fetal research}

Washington. Two days after taking office, US President Bill Clinton overturned a ban on the federal government sponsoring research involving the use of fetal tissue in transplants. In overturning the prohibition, Clinton cited the promise of fetal tissue research in developing treatments for Parkinson's, Alzheimer's disease, diabetes and leukaemia.

The decision opens the way for researchers to apply for grants from the National Institutes of Health (NIH) and also is expected to free up other sources of funding. Eugene Redmond of the Yale University School of Medicine, who has relied on foundations and private individuals to support his work related to Parkinson's, says that foundations and drug companies that otherwise would have considered funding fetal tissue research during the Bush presidency declined because of the federal ban.

Tony Reichhardt 